\title{
INTERPRETAÇÃO CONSTITUCIONAL, IDEOLOGIA E ANÁLISE DO DISCURSO: UM ESTUDO A PARTIR DO PROBLEMA DAS MUTAÇÕES (IN)CONSTITUCIONAIS
}

\author{
CONSTITUTIONAL ADJUDICATION, IDEOLOGY AND DISCOURSE ANALYSIS: A \\ STUDY FROM THE PERSPECTIVE OF (UN)CONSTITUTIONAL INFORMAL CHANGES
}

Glauco Salomão Leite

\begin{abstract}
Professor de Direito Constitucional da Graduação e do Programa de Pós-Graduação em Direito (Mestrado e Doutorado) da Universidade Católica de Pernambuco (UNICAP). Professor de Direito Constitucional da Universidade Federal da Paraíba (UFPB) e da Universidade de Pernambuco (UPE). Membro do grupo de pesquisa REC - Recife Estudos Constitucionais (REC/CNPq).E-mail: glaucosalomao@uol.com.br
\end{abstract}

José Armando de Andrade

Graduado em Letras, Mestre em Linguística, Professor de Português Jurídico e Hermenêutica Jurídica da Asces-Unita. E-mail: armandoandrade@asces.edu.br

Recebido em: 01/03/2017

Aprovado em: 31/07/2017

RESUMO: Apesar de não existir consenso sobre a melhor filosofia e método de interpretação, o debate hermenêutico atual parte da distinção "texto normativo" / "norma jurídica" para destacar a ideia de que a norma não é pré-estabelecida pelo legislador, e sim por construção judicial. As constituições democráticas contemporâneas, ao incorporarem valores substantivos e direitos fundamentais, elevam o poder do juiz constitucional, que deve construir a norma de decisão a partir de uma linguagem abstrata e indeterminada. Admitem-se processos informais de mudança da constituição, operadas, principalmente, por Tribunais Constitucionais, alçados à condição de instituições que conferem a última palavra sobre seu conteúdo. Este trabalho tece críticas a essa narrativa convencional, ressaltando os riscos decorrentes de mutações (in)constitucionais que promovem deturpações no conteúdo da constituição, representando uma expansão excessiva dos poderes da Cortes em detrimento do âmbito de atuação do legislativo. O trabalho questiona as bases doutrinárias que enaltecem o papel criativo dos juízes e suas implicações metodológicas e institucionais. Discute o problema da interpretação sob os aspectos discursivos e sociocognitivos, ancorando-se na abordagem da Linguística Cognitiva, cujos critérios analíticos apontam para a convergência entre texto, mente e sociedade. Ao final, realça os perigos advindos de decisionismos jurídicos que transformam a supremacia da constituição em supremacia judicial.

Palavras-Chave: Interpretação constitucional; ideologia; constituição-viva; mudanças informais.

RESUME: Although there is no consensus on the best philosophy in law adjudication, the contemporary debate in this field starts from the distinction between "legal text" and "legal rule" to highlight the idea that the rule itself is determined by Courts and not by the legislative branch. From this perspective, contemporary democratic constitutions elevate judicial power by incorporating substantive values and fundamental rights on a large scale. Because of this, judges must deliver their opinion from an abstract and indeterminate language. As a consequence, informal changes of constitutional meanings, operated mainly by Constitutional Courts, are 
admitted, especially because those institutions are responsible for the last say about constitutional provisions. The present work offers a critique to this conventional narrative, highlighting the risks from (un)constitution informal changes that distort constitutional meanings, which represents an excessive empowerment of the Courts and an illegitimate intervention in legislative sphere. In order to do so, the work questions theoretical foundations that extol the creative role of the Courts, revealing its methodological and institutional consequences. It also discusses the problem of legal interpretation under the discursive and sociocognitive aspects, anchoring itself in the approach of Cognitive Linguistics, whose analytical criteria point to the convergence between text, mind and society. In the end, it points out the dangers arising from judicial discretion that transform the supremacy of the constitution into judicial supremacy.

Key Words: Constitutional adjudication; ideology; living constitution; informal changes.

SUMÁRIO: Introdução; 1 O formalismo exegético e a supremacia do legislador; 2 A guinada para um positivismo semântico: o juiz como dono da lei e o pesadelo hartiano; 3 A práxis interpretativa rumo ao pragmatismo judicial; 4 Deturpação hermenêutica da Constituição: mutações inconstitucionais; 5 Exemplo de mutação inconstitucional: a Corte contra a presunção de inocência; 6 Modelo Comportamental do STF: uma análise sociocognitiva do discurso; 6.1 Cognição social e interpretação; 6.1 Cognição social e interpretação; 6.2 Texto, discurso, interpretação, modelos mentais e ideologia; 6.3 Voltando à mutação inconstitucional da garantia da presunção da inocência: uma abordagem sociocognitiva do discurso; 6.3.1 Construindo modelos mentais ou frames; Conclusão; Referências Bibliográficas.

\section{INTRODUÇÃO}

Ainda no início da vigência da Constituição Federal de 1988 (CF/88), o STF foi provocado para decidir se a infidelidade partidária configurava hipótese de perda de mandato parlamentar em um contexto no qual a mudança de legenda era prática frequente e reprovável da classe política. Apesar disso, o então Min. Sepúlveda Pertence advertiu: "é fundamental fugir à tentação de inserir no direito positivo as nossas convicções sobre o que ele deveria ser". " No mérito da questão, a Corte endossou o voto do referido magistrado. Por outro lado, o que se verificou nas décadas subsequentes foi o fortalecimento de um discurso legitimador de amplos poderes decisórios do intérprete judicial, autorizando-o, inclusive, a promover alterações que reputar necessárias no direito positivo por razões de "justiça", "equidade" ou para "empurrar a história".

No âmbito do debate hermenêutico, como se sabe, é perceptível a mudança de paradigmas que repercute na natureza, função e nos limites da atividade jurisdicional. Nesse sentido, integra o arsenal do senso comum a afirmação de que está superado o positivismo exegético responsável pela defesa de que o intérprete deve se ater à literalidade dos diplomas legais. Desse modo, o juiz não precisaria mais seguir rigorosamente a "letra fria da lei". No lugar de um modelo rígido de aplicação do direito, emergiram correntes que enalteceram o protagonismo judicial, sem maiores preocupações com mecanismos de controle hermenêutico das decisões judiciais. Em outros termos, foi apenas ressaltada a dimensão do poder do juiz, sem a correspondente dimensão dos limites aos quais o intérprete está vinculado.

Esse problema assume maiores proporções quando o intérprete em questão é um Tribunal, como o STF, cuja posição institucional o torna a instância responsável pela última palavra sobre o sentido da constituição. Além do efeito simbólico derivado da posição sobranceira de uma Suprema Corte, existe um inegável viés técnico-processual: muitos de seus acórdãos possuem efeito vinculante e erga omnes ou podem se converter em súmulas

${ }^{1}$ STF - MS n. 20.916/DF, rel. Min. Carlos Madeira, DJ, de. 11.10.1989.

Revista de Direito Brasileira | São Paulo, SP | v. 19 | n. 8 | p. 315 - 334 |Jan./Abr. 2018 
vinculantes. Eis o que se discute no presente trabalho. Aqui, almeja-se analisar como a retórica a favor de uma ampla margem de discricionariedade judicial pode conduzir a graves deturpações em elementos substantivos da ordem constitucional, como são os direitos fundamentais. Para tanto, recorre-se ao estudo das chamadas mutações constitucionais, destacando-se que, em nome de interpretações supostamente evolutivas, o que denotaria progresso e avanço, têm sido implementadas autênticas mudanças ilegítimas na constituição através de decisões judiciais que instrumentalizam categorias e conceitos abstratos da Teoria do Direito para ocultar preferências pessoais (morais, políticas, econômicas, etc) do intérprete. Somaremos à análise dogmática, uma abordagem sociocognitiva do discurso, cujo lastro teórico será delineado adiante, a fim de observar como o sujeito que decide responde às demandas contextuais e discursivas para ter sua interpretação "aceita" pelo auditório (tomado aqui no sentido amplo da Nova Retórica). Como resultado, verificam-se construções de sentido desconectadas do pacto constituinte, da historicidade subjacente ao documento constitucional e dos precedentes do próprio STF, elevando-se os riscos de deslegitimação democrática da jurisdição constitucional como decorrência do desvirtuamento de suas finalidades institucionais.

\section{O FORMALISMO EXEGÉTICO E A SUPREMACIA DO LEGISLADOR}

Na literatura jurídica, facilmente encontramos trabalhos que nos apresentam as mais variadas teorias ou "Escolas" de interpretação do direito. Porém, isso é reproduzido como se tais teorias constituíssem modelos abstratos desenvolvidos no vazio e sem qualquer relação com a experiência concreta. Ocorre que, como observa Just, as teorias do direito são forjadas e moldadas no interior de contextos histórico-culturais bem definidos, os quais podem ter como efeito, por exemplo, "o de estimular interrogações num determinado sentido mais do que em outro, de limitar o universo de hipóteses cogitáveis ou de restringir a sua verificabilidade" (JUST, 2014, p. 17 e ss). Essa perspectiva ajuda a explicar como o poder do intérprete judicial tem oscilado consideravelmente, tendo em vista as influências políticas e sociais que interferem, em cada tempo histórico, nas teorias da interpretação do direito. Assim, como tipos ideais situados em polos antagônicos, convém fixar um contraponto entre um modelo exegético, que almeja amarrar ao máximo o juiz ao texto legal, com aquele outro que lhe confere amplos espaços de liberdade e autonomia para decidir.

Nesse sentido, o modelo do Estado de Direito liberal, oriundo das revoluções burguesas do final do século XVIII, assentou-se no primado da lei no arcabouço das fontes formais do direito. Considerando que tais revoluções se voltaram contra as monarquias absolutistas, é compreensível o deslocamento de poder político na reorganização do Estado: retira-se do rei, passando-o para os parlamentos, enquanto instituições representativas da vontade geral da coletividade. Desse modo, com a confiança depositada no legislador, coibia-se o arbítrio praticado pelos órgãos e agentes do Poder Público através de leis gerais e abstratas. Ao mesmo tempo em que se promovia o enquadramento dos entes públicos na legalidade parlamentar, também eram protegidas as liberdades públicas, a autonomia da vontade e a propriedade, valores caros ao Estado liberal. Consequentemente, a lei parlamentar não é vista como simples imposição de poder, senão como resultado do consentimento entre indivíduos dotados de razão (OTTO, 1995, p. 132).

Some-se a tais fatores a circunstância de que pairava forte descrença sobre os juízes. Os magistrados estavam comumente associados ao Antigo Regime em razão dos privilégios de que gozavam. Por isso, apresentavam-se como adversários de qualquer reforma política liberal, tornando-se conhecidos como a nobreza de toga (CAPPELLETTI, 1999, p. 97.). Sendo assim, quanto menor fosse o poder dos juízes, maiores seriam a proteção e a segurança dos indivíduos na maneira como as Cortes deveriam aplicar o direito. Em outras palavras, o direito não seria aquilo que juízes dizem que ele é, ao contrário do realismo jurídico. 
Nessa ambiente marcado pela hegemonia política dos parlamentos e pela "Era das Codificações", cujo paradigma é o Código Civil de Napoleão (1804), desenvolveu-se o positivismo legalista representado pela "Escola da Exegese" (École de l'exégèse). Alguns de seus elaboradores chegaram a reconhecer lacunas e insuficiências na nova lei, mas seus primeiros intérpretes (os exegetas) não admitiram a existência de tais "defeitos", afirmando que não havia atos da vida social que não estivessem previstos e regulados pelo Código. Com o monopólio da produção normativa no Poder Legislativo, supera-se o estágio anterior marcado pela dispersão e fragmentação das fontes do direito, acolhendo a ideia de consenso nacional simbolizada nas leis e nos códigos. Desse modo, o direito reduz-se à lei criada pelo legislador. Nota-se a relação que se estabelece entre o legislador e o juiz. Por trás da primazia da lei como fonte do direito, está o caráter superior do Poder Legislativo em relação aos demais poderes, de modo que os comandos legais são emanados de "cima para baixo".

É claro que esses elementos repercutem numa teoria da interpretação construída sob o pressuposto da credibilidade do legislador e da desconfiança sobre o juiz. Assim, diante dos atributos da clareza e exatidão presentes a lei, o que fez brotar um fetiche ao texto legal, competia ao intérprete tão-somente identificar o sentido único de seus enunciados para aplicá-lo ao caso concreto. Qualquer forma de abertura que implicasse alguma margem de discricionariedade na interpretação seria sinônimo de arbítrio judicial. A única questão seria saber interpretar o direito e extrair o sentido verdadeiro dos textos legais. Segundo a Escola da Exegese, o jurista só cumpriria seu papel de aplicador da lei se a interpretasse lógica e gramaticalmente, de conformidade com a intenção original do legislador.

No contexto do paradigma liberal de Estado de Direito, e para atender ao ideal de segurança jurídica, advertiu o Barão de Montesquieu: "os julgamentos devem se basear num texto preciso de lei. Se fossem uma opinião particular do juiz, viveríamos em sociedade sem saber precisamente os compromissos que ali assumimos" (1996, p. 170). Prevalecia, portanto, a máxima "in claris cessat interpretatio". A rigor, como destacado por Perelman (2004, p. 50), as noções de "clareza" e "interpretação" são antitéticas na tradição do positivismo exegético, ou seja, a melhor lei seria aquela que não precisasse ser interpretada.

Logo, em vez de se falar em construção da norma jurídica pelo juiz, fala-se em declaração da norma já existente e acabada. A norma jurídica é um dado e não um construído. Oculta-se o aspecto volitivo na atividade interpretativa, evidenciando apenas o aspecto cognitivo ou de conhecimento da lei. O intérprete judicial vê-se circunscrito a rigorosos parâmetros previamente definidos pelo legislador. Esse aspecto representa a projeção para o campo da teoria do direito da ideia iluminista da doutrina da separação dos poderes, que propugna a distinção entre política e direito. Assim, enquanto a influência política é legítima na esfera do governo e do legislador, ela é inaceitável na jurisdição, que deve se orientar pelo ideal de neutralidade na aplicação das normas. Nesse sentido, observa Ferraz Jr. (2000, p.347) que o princípio não era de separação dos poderes, mas de inibição de um pelo outro de forma recíproca, de sorte que o Judiciário era o que menos tinha a ver com força política. Depreende-se, portanto, que não há um ambiente favorável para ativismos judiciais, nem para politização das Cortes, pois qualquer avanço dos poderes decisórios dos juízes significaria um ilegítimo excesso de poder e quebra da exigência de neutralidade sobre questões políticas, cabendo-lhes um papel mais modesto, cauteloso e moderado na aplicação do direito.

\section{A GUINADA PARA UM POSITIVISMO SEMÂNTICO: O JUIZ COMO DONO DA LEI E O PESADELO HARTIANO}

O positivismo jurídico é uma das correntes mais influentes na Ciência do Direito e, ao mesmo tempo, uma das que mais suscitam divergências e incompreensões. Na doutrina brasileira, é comum referir-se ao positivismo como uma teoria fracassada, ortodoxa e 
politicamente perigosa. Atribuir a um jurista o rótulo de positivista pode soar como uma acusação grave e um ataque à honra de tão pejorativa que a expressão se tornou. O problema da retórica antipositivista é que ela termina por não perceber que o positivismo jurídico se afigura como uma complexa linha de pensamento que alberga perspectivas doutrinárias distintas, sobretudo no campo da interpretação do direito (DIMOULIS, 2016, pp. 66 e ss). Com efeito, a afirmação de que ser positivista significa aplicar "a letra fria" da lei, numa atitude de um simples desvelamento de significados preexistentes, não pode ser generalizada para todos os autores que se intitulam positivistas. Como visto anteriormente, a suspeição sobre os juízes e a legitimidade democrática das Assembleias contribuíram para a concepção de uma vertente formalista na interpretação do direito, demandando dos magistrados um maior apego aos elementos textuais das leis. Para essa variante positivista, pode-se dizer que o intérprete está mais fortemente vinculado aos enunciados linguísticos das normas, tendo como resultado um espaço reduzido de aplicação do direito.

Entretanto, dois dos maiores expoentes do positivismo do século XX, Hans Kelsen e Herbert L.A. Hart, distanciam-se sobremodo do formalismo exegético e apresentam argumentos que permitem a discricionariedade do intérprete. Nas poucas páginas que dedica ao problema da aplicação do direito, Kelsen (1985, p. 366) critica o que ele denomina "teoria usual da interpretação", que defende que as leis já trazem uma única resposta correta para cada situação concreta de aplicação da norma, competindo ao intérprete tão-somente descobrir tal resposta através de um processo de compreensão e clarificação da lei. Para o autor, ao revés, a norma jurídica se apresenta como uma "moldura", que permite diversas possibilidades de interpretação. A moldura seria a responsável pelo elenco das possibilidades semânticas do texto legal. Diante dessas alternativas, o aplicador opta por uma delas e cria a norma de decisão. A escolha por uma das possíveis interpretações admitidas pela moldura consiste em um ato de vontade do aplicador e não apenas em um ato de conhecimento, inserindo-se no campo da política judicial. Na síntese de Ferraz Jr., cuida-se de um "eu quero" e não de um “eu sei” (1994, p. 261).

Ao proceder dessa maneira, Kelsen não confere qualquer importância aos métodos de interpretação, haja vista que, ao fim e ao cabo, o sentido adotado refletirá a escolha subjetiva do intérprete, de modo que tais métodos conduzirão apenas a uma resposta possível, dentre outras igualmente legítimas. $\mathrm{O}$ fato é que, sem qualquer parâmetro ou critério que oriente e discipline a atividade hermenêutica, a tarefa interpretativa se converte em um poder arbitrário, ainda que esse resultado não tenha sido pretendido pelo autor. Como captado por Dimoulis, isso equivale ao reconhecimento de uma competência ilimitada: "faça o que quiser" (2006, p. 212).

A princípio, a proposta kelseniana poderia sugerir algum limite à atividade interpretativa, pois as interpretações admissíveis seriam apenas aquelas compreendidas pela moldura da norma. Logo, as que se situassem fora de tal moldura, deveriam ser rejeitadas. $\mathrm{O}$ problema é que caberá ao próprio intérprete fixar os limites da moldura e, consequentemente, os limites do seu próprio poder de decisão. Como consequência, há uma perigosa abertura para excessos cometidos por juízes que poderão decidir em qualquer direção, apenas orientados pela suposta moldura, cujos horizontes semânticos serão delineados por eles próprios. A rigor, se pensarmos que uma teoria da interpretação deve ter um caráter normativo, prescrevendo os critérios e limites da prática decisória, o normativismo kelseniano falha, na medida em que equipara a interpretação a um mero ato (incontrolável) de vontade. Por outro lado, não se pode dizer que o positivismo jurídico, ao menos na versão do Mestre de Viena, defende um apego à letra da lei. Ao revés, seguindo sua trilha, em vez de amarras, o intérprete encontra estímulos para construções elásticas, e até abusivas, aproximando-se do realismo jurídico.

Em sentido semelhante, Hart (2005, pp. 137 e ss) compreende que o direito apresenta uma linguagem com textura aberta e tal circunstância leva à discricionariedade judicial (STRUCHINER, 2002). Considerado um dos principais filósofos do Direito do século XX, responsável por uma reformulação teórica sofisticada do positivismo normativista, Hart se insere na tradição da filosofia analítica, tal como Kelsen e o Círculo de Viena, de modo que suas 
preocupações estão ligadas à criteriosa descrição do direito, isto é, ao modo como os sistemas jurídicos se apresentam e funcionam objetivamente. Por isso, não propõe uma teoria normativa, cujo objetivo seria discutir como o direito deveria ser. Nesse sentido, o autor parte da premissa segundo a qual o direito é um sistema de regras jurídicas, que oferecem padrões de decisão para uma série de casos concretos. Porém, existem casos para os quais as regras existentes são imprecisas, situando-se numa zona de penumbra (hard cases). Assim, diante da indeterminação linguística do direito, o juiz deve se valer de seu poder discricionário para resolver o caso concreto. Dito de outro modo, o problema da textura aberta do direito é resolvido através de uma delegação de poder ao juiz.

No entanto, Hart é um crítico do realismo jurídico. Ao se surpreender com a extensão dos poderes da Suprema Corte americana, no contexto do protagonismo do Tribunal em relação à legislação social do New Deal, afirmou que, aos olhos de um advogado inglês, tais poderes seriam dificilmente justificáveis em uma democracia (HART,1983,p. 125). Diante daquele incomum funcionamento dos Tribunais estadunidenses, destacou que as doutrinas jurídicas que buscavam explicar esse fenômeno judicial têm oscilado entre dois extremos: o pesadelo (the nightmare) e o nobre sonho (the noble dream). O pesadelo é representado exatamente pelas vertentes do realismo jurídico norte-americano, especialmente as que ganharam força nas décadas de 1920 e 1930 e que constituíram uma "revolta contra o formalismo" (HART, 1983, p.130). Tal corrente seria a responsável por desfazer a ilusão de que o juiz é alguém objetivo, imparcial, erudito e experiente como agente que declara o direito. O nobre sonho corresponderia à crença de que os juízes, apesar de situações de indeterminação da linguagem, aplicam regras préestabelecidas em leis, conceitos e precedentes, sem que seus juízos políticos ou morais distorçam tais parâmetros. O juiz atuaria como um porta-voz dos mortos e da tradição jurídica (REIS, 2012, p. 156).

Curiosamente, apesar da referida postura crítica ao realismo, tendo em vista que Hart não apresenta critérios de controle da discricionariedade judicial, acaba incorrendo nos mesmos problemas da teoria kelseniana. A textura abertura da linguagem do direito produz incertezas e ambiguidades, que apenas são colmatadas por um ato (político) do juiz, ao determinar o sentido que irá prevalecer. Nesse caso, o pesadelo se transforma em realidade e o juiz, apropriando-se da vagueza da linguagem jurídica, transforma-se em dono da lei, com evidentes implicações para qualquer democracia constitucional, pois a discricionariedade se converte em arbitrariedade (STRECK, 2008 p. 390).

Em contrapartida, encontramos uma importante ressalva no pensamento de Kelsen (2003, pp. 160-170) quanto aos riscos presentes na prática dos Tribunais. Apesar de ter sido um dos idealizadores do modelo de jurisdição constitucional que se expandiu na Europa ao longo da segunda metade do século XX, Kelsen não defendia a existência de Tribunal Constitucional dotado de amplos poderes de fiscalização do legislador democrático, pois, em sua visão, uma Corte superpoderosa também traria problemas para o sistema democrático. Importante ressaltar que a defesa de um tribunal ad hoc, vocacionado para a tutela da ordem constitucional, apareceu como um contraponto a uma longa tradição europeia de hegemonia dos Parlamentos, assentada, ainda, numa doutrina liberal sobre a separação dos poderes. Desse modo, embora apresentasse argumentos consistentes a favor da jurisdição constitucional, Kelsen revelou cautela ao atribuir à Corte Constitucional uma função mais comedida. Por isso, assevera categoricamente que o Tribunal deve ser abster de decidir com base em princípios jurídicos, pois, diante da imprecisão e abertura que caracterizam esses preceitos, haveria o risco de um deslocamento de poder da esfera parlamentar para o Tribunal. Em outras palavras, Kelsen desconfia dos perigos de uma aplicação equivocada dos princípios jurídicos, notando os desvios hermenêuticos que poderiam ocorrer em nome da aplicação dessas normas, ou seja, o Tribunal poderia impor suas visões políticas, morais e econômicas ao legislador democrático sob o argumento de que estaria concretizando princípios jurídicos. 
Feita essa advertência quanto ao pensamento kelseniano, que reflete muito mais uma visão política acerca da função dos Tribunais Constitucionais, mantém-se a crítica de que o positivismo normativista impulsiona decisionismos judiciais. $\mathrm{O}$ mesmo se pode afirmar sobre a doutrina hartiana em relação à textura aberta do direito, que aposta na discricionariedade judicial para superar os problemas de inconsistência e ambiguidade dos preceitos legais.

Se Kelsen temia a aplicação abusiva de princípios jurídicos e Hart buscou rejeitar o pesadelo do realismo jurídico, a doutrina brasileira vivencia o pior dos mundos: a junção da principiologização do direito com ampla discricionariedade judicial.

\section{A PRÁXIS INTERPRETATIVA RUMO AO PRAGMATISMO JUDICIAL.}

O paradigma do Estado Constitucional contemporâneo, emergente dos processos de redemocratização na Europa e na América Latina na segunda quadra do século passado, reflete uma substancial reestruturação do Estado e do Direito, com profundos impactos nas teorias da interpretação jurídica. Desta feita, partindo-se da ideia de que o respeito aos direitos fundamentais, sobretudo das minorias, não poderia depender exclusivamente da vontade política das maiorias ocasionais, expandiu-se a jurisdição constitucional como instância contramajoritária, cujo objetivo principal é a proteção das novas constituições democráticas. Assim, a ampla constitucionalização de direitos e valores substantivos ensejou uma inédita configuração nos arranjos institucionais. Ao mesmo tempo em que se impõem limites mais rigorosos à liberdade de conformação do legislador e aos processos democráticos majoritários, eleva-se o campo de atuação da jurisdição constitucional. O "império da lei” é substituído pelo "império da Constituição", cuja muralha está sob a guarda dos Tribunais Constitucionais.

No ambiente europeu pós-Segunda Guerra, sobretudo na Alemanha, observa-se o advento de novas perspectivas teóricas do pensamento jurídico que se contrapunham ao formalismo até então prevalecente. Destacam-se, a propósito, a ideia de força normativa da Constituição de Konrad Hesse, a metódica estruturante de Friedrich Müller, o resgate da tópica por Theodor Viehweg, a abertura da sociedade dos intérpretes da Constituição de Peter Häberle e a teoria dos direitos fundamentais de Robert Alexy (JUST, 2014, p. 72). A influência do pensamento alemão, vinculado a uma leitura constitucional especificamente axiológica e em uma dimensão principiológica, foi significativamente intensa, sobretudo a partir da valorização dos discursos que condensavam no ideal da "dignidade humana" a realização dos direitos fundamentais.

Ocorre que, no Brasil, a importação de tais discursos, especialmente no ambiente pós88, criou um universo retórico que tem estimulado práticas ativistas ilegítimas por parte da justiça constitucional (LEITE; TEIXEIRA, 2016). De um lado, é compreensível que, diante do tradicional conservadorismo jurídico (e político) que caracterizou por décadas a prática decisória dos Tribunais pátrios, levando-os a pecar muito mais por omissão do que por excesso, as novas correntes teórico-metodológicas, reunidas em torno do antiformalismo e da efetiva concretização constitucional, acabaram caindo como uma luva pela ascensão institucional do Poder Judiciário. Com efeito, a distinção entre "texto" e "norma" (e a plurivocidade semântica dos textos), a compreensão da constituição como sistema aberto de regras e princípios, a utilização do método da ponderação e o apelo à razão prática são apenas alguns dos elementos que fazem parte desse arsenal doutrinário que eleva o papel e a responsabilidade do juiz constitucional.

Por outro lado, o manuseio equivocado desses referenciais teóricos, e das categorias que as integram, pode camuflar um jogo do poder por meio do qual se almeja expandir o poder judicial para além dos limites constitucionais, conferindo-lhe foros de legitimidade. Ao final, tais doutrinas acabam sendo instrumentalizadas para ocultar um crescente protagonismo dos Tribunais no afã de corrigir os desvios e déficits das instituições representativas, atrelado a uma não menos indesejável politização da justiça. Dessa maneira, o mito do juiz preso à legalidade 
estrita é bastante enfraquecido diante do juiz vinculado à constituição, que lhe franqueia amplos horizontes interpretativos, convidando-o a construções hermenêuticas nem sempre coerentes com o documento constitucional. Afinal, a constituição é um sistema aberto, que incorpora valores, e se apresenta através de uma linguagem indeterminada, sobretudo em relação aos direitos fundamentais, que possuem natureza de princípios jurídicos, sujeitos a ponderações.

Bem se vê que esse roteiro pode transformar a constituição em soft law, de modo que sua força normativa, tão cara ao constitucionalismo democrático atual, dilui-se na plêiade de significados que podem ser livremente escolhidos pelo intérprete judicial e o documento constituinte assume os contornos que este lhe atribuir livremente. Representativo desse quadro é o pensamento do ex-ministro Eros Grau, para quem "não existe a Constituição de 1988 [...] o que hoje realmente há, aqui e agora, é a Constituição do Brasil, tal como hoje, aqui e agora, ela é interpretada/aplicada por esta Corte". ${ }^{2}$ O mesmo foi dito pelo Min. Luiz Fux em recente discussão travada no Tribunal Superior Eleitoral com o Min. Gilmar Mendes. O primeiro, ao asseverar que o "direito é aquilo que os Tribunais dizem que é", foi fortemente questionado pelo segundo, que rebateu afirmando: "O Supremo não faz do quadrado redondo. Data vênia. Isso não é conceito que se possa sustentar" (PIRES, 2016).

Essa inclinação pelo judicialismo ignora uma premissa elementar, pois o próprio texto normativo, enquanto vertido em linguagem minimamente compreensível pelos seus utentes no contexto comunicacional, constitui relevante limite hermenêutico: "o texto limita a concretização e não permite decidir em qualquer direção, como querem as diversas formas de decisionismo". (ADEODATO, 2006, p. 331). Ao insistir nessa forma de pragmatismo judicial, promove-se um retorno ao positivismo semântico de cariz kelseniano e hartiano, apostando-se na ampla discricionariedade judicial. Com isso, evidencia-se o caráter retórico do uso das correntes hermenêuticas contemporâneas, que, além de não serem aplicadas corretamente, não conseguem cumprir sua função básica enquanto teorias interpretativas: a restrição e o controle da prática decisória.

\section{DETURPAÇÃO HERMENÊUTICA DA CONSTITUIÇÃO: MUTAÇÕES INCONSTITUCIONAIS}

Em meio a tanta maleabilidade no uso de teorias hermenêuticas, sobressai um problema sensível que toca o papel do guardião da Constituição diante do próprio bem a ser protegido: as transformações informais do texto constitucional. Na literatura nacional, um dos trabalhos precursores sobre o tema foi o de Ferraz (1986). Nele, a autora compreende as mutações constitucionais como mudanças informais que culminam na "alteração, não da letra ou do texto expresso, mas do significado, do sentido e do alcance das disposições constitucionais", destacando, ainda, que elas ocorrem lentamente, e só se tornam claramente perceptíveis quando se compara o entendimento atribuído às cláusulas constitucionais em momentos diferentes, cronologicamente afastados um do outro, ou em épocas distintas e diante de circunstâncias diversas." (FERRAZ, 1986, p. 09).

De uma maneira geral, as mutações constitucionais têm sido aceitas como práticas legítimas, ao menos se respeitados alguns limites. Parte-se da ideia de que os documentos constitucionais, para além dos mecanismos de reforma em seu texto, devem permanecem abertos em seu conteúdo e significado, para que possam acompanhar a própria dinâmica da experiência histórica. Desse modo, evita-se que caiam no anacronismo. Nessa perspectiva, a Lei Fundamental não é vista como um texto estático, e sim como uma living constitution, capaz de se acomodar

\footnotetext{
${ }^{2}$ Voto proferido na ADI n. 3.367/DF, rel. Min. Cezar Peluso. Essa forma de compreender a importância da interpretação judicial desenvolvida por uma Suprema Corte ou Tribunal Constitucional remonta à conhecida observação feita pelo então Justice da Suprema Corte norte-americana Charles Hughes, que afirmou: "Nós vivemos sob uma Constituição, mas a Constituição é aquilo que a Suprema Corte diz que ela é."
} 
diante de transformações sociais relevantes. Por se cuidar, em essência, de uma mudança pela via interpretativa, ainda que a mutação constitucional possa ser realizada pelos poderes Legislativo e Executivo, diante do protagonismo dos Tribunais, estes passaram a ser os principais agentes responsáveis por tais mudanças. No direito americano, são emblemáticas as decisões da Suprema Corte em Brown vs. Board Education (1954) e Roe vs. Wade (1973). No primeiro caso, a Corte, abandonando a doutrina dos "separados, mas iguais", reconheceu a ilegitimidade das discriminações raciais nas escolas a partir uma interpretação evolutiva do princípio da igualdade. No segundo, decidiu-se pelo direito ao aborto com fundamento no preceito constitucional que reconhece o direito à privacidade.

Nada obstante, para fins de uma mudança informal legítima na constituição, convém levar em conta não apenas os limites semânticos que o texto estabelece de antemão, e que são fruto de uma paulatina construção sociocultural, bem como as contribuições de uma dogmática jurídico-constitucional consistente, que não se confunde com um dogmatismo meramente exegético. Tais elementos são relevantes para se evitar que uma Suprema Corte acabe invadindo a esfera do legislador democrático, produzindo, na prática, uma emenda constitucional através de seus acórdãos. Nessa hipótese, haveria uma mutação inconstitucional. Isso aumenta a necessidade de um permanente controle hermenêutico das decisões das Cortes Constitucionais. Sua legitimidade não advém apenas de formas e estruturas. Nesse sentido, as decisões do STF não se revestem de legitimidade apenas porque existe uma regra de competência prevista na constituição que lhe outorga a função de seu guardião. Tal legitimidade depende sobretudo da maneira concreta como o Tribunal desempenhará sua tarefa, o que aponta para uma avaliação que não se deixe seduzir pelos mitos e simbologias que rodeiam e enaltecem o STF, exigindo-se uma análise crítica da qualidade intrínseca de suas sentenças.

Como bem destacou David Strauss (2010, p. 03), uma “constituição viva” é uma constituição manipulável. Se a constituição, continua o autor, não é um documento estático - se ela está mudando de tempos em tempos - então alguém está fazendo tais alterações. E esse "alguém", por certo, está promovendo essas mudanças de acordo com a sua visão sobre o que é esta constituição. Logo, se se pensa que esse "alguém” é um grupo de juízes, consequentemente a constituição não passaria de uma coleção de ideias que tais intérpretes, por ocuparem cargos de poder num determinado momento, impuseram a toda comunidade política. Porém, em tempos de juristocracia excessiva, é importante lembrete de Fisher (1998, p. 276): a Corte não é a Constituição.

\section{EXEMPLO DE MUTAÇÃO INCONSTITUCIONAL: A CORTE CONTRA A PRESUNÇÃO DE INOCÊNCIA}

Impulsionado em conferir efetividade à jurisdição, o STF Corte fixou novo entendimento acerca do alcance da garantia individual da presunção de inocência prevista no artigo $5^{\circ}$, LVII, da CF. Desde o precedente firmado no HC n. 84.078/MG, de 2009, o Tribunal vinha reconhecendo que não poderia haver execução provisória de condenação criminal, já que era necessário aguardar o trânsito em julgado da sentença. De acordo com a nova orientação, a decisão proferida com a condenação por Tribunais de segunda instância, mesmo cabendo recurso, o réu já será obrigado a iniciar o cumprimento da pena ${ }^{3}$. Nesse caso, não estamos diante de um exemplo de "interpretação evolutiva" da "constituição viva" ou de mutação constitucional. A rigor, verifica-se uma mutação inconstitucional.

No referido julgamento do HC n. 126.292, a maioria da Corte foi conduzia pelo voto do Min. Teori Zavaski, sendo dissidentes os Min. Marco Aurélio, Celso de Mello, Ricardo Lewandowsky e Rosa Weber. Em sua fundamentação, o Min. Zavaski iniciou ressaltando duas

\footnotetext{
${ }^{3}$ HC n. 126.292, rel. Min. Teori Zavaski, d.j. 17.02.2016. Tal posição foi posteriormente ratificada no julgamento das ADCs n. 43 e 44, rel. Min. Marco Aurélio.
}

Revista de Direito Brasileira | São Paulo, SP | v. 19 | n. 8 | p. 315 - 334 |Jan./Abr. 2018 
questões que deveriam ser enfrentadas no equacionamento da controvérsia: (a) o alcance do princípio da presunção da inocência aliado à (b) busca de um necessário equilíbrio entre esse princípio e a efetividade da função jurisdicional penal, que deve atender a valores caros não apenas aos acusados, mas também à sociedade, diante da realidade de nosso intricado e complexo sistema de justiça criminal.

A respeito do princípio da presunção de inocência, o referido magistrado não deixou de tecer considerações sobre a relevância desta garantia constitucional para um processo criminal condizente com o Estado de Direito. De tal garantia, decorreria a necessidade de existir "reserva de dúvida acerca do comportamento contrário à ordem jurídica" atribuído ao acusado. Porém, seguiu discorrendo o Ministro, "a eventual condenação representa, por certo, um juízo de culpabilidade, que deve decorrer da logicidade extraída dos elementos de prova produzidos em regime de contraditório no curso da ação penal". Assim, a sentença condenatória em primeiro grau significaria a superação da presunção de inocência por um juízo de culpa, "embora não definitivo, já que sujeito, se houver recurso, à revisão por Tribunal de hierarquia imediatamente superior.". Na sequência, o Min. Teori Zavaski argumentou que é precisamente perante os Tribunais de segunda instância que se exaurem as possibilidades de discussão sobre fatos e provas que levaram à condenação do acusado: "noutras palavras, com o julgamento implementado pelo Tribunal de apelação, ocorre espécie de preclusão da matéria envolvendo os fatos da causa.".

$\mathrm{O}$ argumento, como se vê, parte de premissas questionáveis. Em primeiro lugar, é preciso reconhecer que o modelo adotado pela $\mathrm{CF} / 88$ acerca da presunção de inocência determina que "ninguém será considerado culpado até o trânsito em julgado de sentença penal condenatória" (art. 5, LVII). Além disso, o art. 283, do Código de Processo Penal (CPP), reproduz, como não poderia ser diferente, a regra constitucional nos seguintes termos:

Ninguém poderá ser preso senão em flagrante delito ou por ordem escrita e fundamentada da autoridade judiciária competente, em decorrência de sentença condenatória transitada em julgado ou, no curso da investigação ou do processo, em virtude de prisão temporária ou prisão preventiva.

Logo, o sentido manifesto tanto do texto constitucional, quanto do CPP, é de que o cumprimento da pena em processos criminais depende do trânsito em julgado da sentença condenatória. Portanto, o preciso momento a partir do qual alguém pode ser considerado culpado é com o trânsito em julgado da condenação e não com a sentença de primeira instância, nem com o acórdão de Tribunal de segundo grau. Duvidosa, desse modo, a ideia segundo a qual com a sentença condenatória em primeira instância a presunção de inocência restaria "superada" por um juízo de culpa. A CF não autoriza tamanha antecipação de culpa.

Além disso, a circunstância de que nos Tribunais de segundo grau se encerram as oportunidades para discutir a valoração de fatos e provas não significa reconhecer o trânsito em julgado de eventual condenação por tais Cortes. Ora, por "trânsito em julgado", como determina a CF, quer-se afirmar que não há mais possibilidade de recurso algum contra a decisão condenatória. Em suma, as alternativas de defesa do réu teriam se esgotado. Se é assim, não há como tornar definitiva a formação de culpa por Tribunal de segundo grau se contra sua decisão ainda cabem recurso especial (por violação à legislação federal) e/ou recurso extraordinário (por violação à $\mathrm{CF}$ ). $\mathrm{O}$ fato de que, em tais recursos, não se admitir a rediscussão de fatos e provas certamente não é o mesmo que sustentar que não se pode questionar coisa alguma. Tanto é assim que, segundo o decano do Tribunal, o Min. Celso de Mello, pelo menos 25\% dos recursos em matéria criminal que chegam ao STF são acolhidos integralmente ${ }^{4}$. Portanto, ao menos perante

\footnotetext{
${ }^{4}$ Matéria publicada sob o título "Presunção de inocência: Celso de Mello e Marco Aurélio comentam mudança na jurisprudência do STF". In: Revista Consultor Jurídico, 18 de fevereiro de 2016. Acesso em 18.02.2016.

Revista de Direito Brasileira | São Paulo, SP | v. 19 | n. 8 | p. 315 - 334 |Jan./Abr. 2018
} 
nosso sistema constitucional, as decisões de segundo grau, porque passíveis de recurso, não podem diminuir a presunção de inocência de alguém.

Sob outro viés, o Min. Teori Zavaski argumentou a necessidade de equilibrar a garantia da presunção de inocência com a efetividade da função jurisdicional em matéria penal, em ordem a resguardar "valores caros" à sociedade. Embora isso não tenha sido referido em seu voto, a referência à ideia de equilíbrio sugere tratar a presunção de inocência como princípio jurídico a ser ponderado com outros interesses, o que, ao menos em tese, justificaria flexibilizações mediante sopesamentos. Pois bem, no caso em tela, ao determinar que "ninguém será considerado culpado até o trânsito em julgado de sentença penal condenatória", a CF garantiu a presunção de inocência através de regra jurídica e não de princípio. Em outras palavras, o constituinte fez uma escolha clara em condicionar o cumprimento da pena ao trânsito em julgado da condenação, de modo que ninguém será tratado como culpado antes desse momento. Argumentos como o da morosidade do Poder Judiciário, número elevado de recursos e sentimento de impunidade da "sociedade" não são juridicamente legítimos para relativizar uma garantia constitucional. Não estamos diante de um hard case. A rigor, tecnicamente, o caso é de fácil solução. Nesse sentido, se a teoria dos princípios foi a linha argumentativa pensada pelo magistrado, a presunção de inocência, tal como prevista na $\mathrm{CF}$, não é princípio, e sim regra. $\mathrm{E}$, como tal, deveria ter sido aplicada em toda sua inteireza.

Além disso, o magistrado considerou que o ajuizamento de recursos perante os Tribunais Superiores poderia ser causa de impunidade, pois, diante da morosidade do Poder Judiciário, haveria o risco de se alcançar a prescrição, ocasionando a extinção de punibilidade do crime. Trata-se de argumento meramente consequencialista, sem qualquer respaldo constitucional. A lentidão do Poder Judiciário não legitima subverter o sentido de um preceito constitucional. Afinal, os direitos e garantias individuais consubstanciam escudos do indivíduo em face do próprio Estado, de modo que a persecução penal só pode ser validamente conduzida se realizada dentro das regras do jogo fixadas constitucionalmente. $\mathrm{O}$ fato de existir morosidade no Poder Judiciário não é motivo suficiente para relativizar uma importantíssima garantia constitucional, como o é a presunção de inocência. Pensar dessa maneira é transferir para o cidadão o peso da falta de uma política séria, racional e minimamente eficiente contra a morosidade .

Em vez de o STF envidar esforços como protagonista de um diálogo institucional na formulação de uma política judiciária consistente que levasse em conta a celeridade processual, reformulação do Direito Processual Penal e redução de suas próprias competências (que inviabilizam uma parcela de sua atividade), elegeu o pior meio para resolver problemas do próprio Judiciário: retroceder na tutela dos direitos fundamentais.

Neste cenário, considerando que a decisão afrontou literalmente um enunciado constitucional de sentido clarividente, o STF não atuou apenas como "legislador positivo". Tampouco atuou como poder reformador, pois os direitos e garantias individuais não podem ser esvaziados nem por emendas constitucionais (art. 60, $4^{\circ}, \mathrm{CF}$ ). A Corte se transubstanciou em poder constituinte permanente, ou seja, em autoridade política soberana, capaz de reescrever cláusulas constitucionais como lhe aprouver. E esse modo de agir compromete sua própria autoridade e legitimidade.

\section{MODELO COMPORTAMENTAL DO STF: UMA ABORDAGEM SOCIOCOGNITIVA DO DISCURSO}

Como discutido anteriormente, a questão da mutação constitucional reside na atitude interpretativa de um Tribunal (no caso deste trabalho, o STF). E por envolver a interpretação constitucional, um elemento muitas vezes negligenciado no processo interpretativo é o sujeito que interpreta. Isso se dá, muitas vezes, pela ausência de uma concepção de interpretação pela doutrina, visto que, com frequência, noções como "extrair o sentido", "descobrir o sentido", 
"percepção clara e exata da norma" são recorrentes na doutrina jurídica para a justificação de interpretações e/ou aplicações das normas em determinadas situações. Contudo, essas noções pressupõem um sujeito intérprete higienizado de questões políticas, sociais e jurídicas, como se a função que desempenha fosse condição suficiente para legitimar a interpretação que atribui à norma. Aí reside o problema.

Tal quadro torna-se ainda mais complexo quando se ignora a dimensão humana do intérprete e trata o processo de interpretação como etiquetagem, como se o sentido estivesse apenas na norma ou adviesse de uma operação puramente racional do intérprete que chega à conclusão objetiva sobre o sentido "exato" ou "claro" da norma jurídica.

Para fins de análise deste trabalho, tomaremos emprestadas algumas noções cruciais da Linguística a fim promover uma análise interdisciplinar, tornando possível um diálogo que leve em consideração o texto, o discurso e a interpretação como processos que se constituem na e pela linguagem, advindos não de uma operação mental solipsista, mas de um sujeito historicamente situado e imerso em conhecimento público socialmente compartilhado e construído, percebido e estocado em sua mente através de modelos mentais.

Para tanto, destacaremos algumas concepções que irão fundamentar esta análise, e que serão fundamentais para pontuarmos a crítica que se fará às mutações (in)constitucionais e os limites jurídicos da interpretação, sobretudo a constitucional. Entende-se que, para se compreender os processos de interpretação e construção das mutações constitucionais, a dimensão intérprete-texto é insuficiente para dar conta da complexa relação que permeia tais processos.

As noções nodais serão: texto, discurso, interpretação, modelos mentais e ideologia. Tais noções serão discutidas sob o prisma da Linguística Cognitiva.

\subsection{Cognição social e interpretação}

Assumimos neste trabalho uma concepção da língua que não se limita a questões sistêmicas ou formais. Inserimo-nos, aqui, numa perspectiva sociocognitivista da linguagem, isto é, uma abordagem teórica da linguagem que considera a produção de sentidos em aspectos linguísticos, mentais e socioculturais. Tal posição sugere assumir concepções a respeito da linguagem que não isolam áreas do saber e requerem postura interdisciplinar para o tratamento da questão. Além disso, procuraremos inserir tais discussões na esfera jurídica, o que aumenta o desafio na construção de proposições teóricas assumidas, haja vista a formalidade e as concepções sobre a linguagem das leis e dos procedimentos processuais e decisionais que, em larga medida, ainda caracterizam o Direito, preso a modelos lógicos e formais - por razões sociais e culturais.

Parte-se do pressuposto, com base em Falcone (2011), Marcuschi (2005), RodriguesLeite (2007) e Sousa Santos (1987) que teorias sobre o mundo são perspectivas de tratamento discursivo da realidade, e não espelhamento ou comprovação vericondicional dos objetos do discurso. Os sentidos são negociados publicamente de forma interativa, cujo lastro social e cultural incide em sua constituição proposicional. Van Dijk (2005) já nos alerta que a validade de uma teoria (seja científica ou do senso comum) não se dá por uma logicidade ou cientificidade interna, mas por critérios de validação social e discursiva, bem como relações de poder.

Assim, tratamos a comunicação e o processo de interação/interpretação do discurso como uma construção sociocognitiva, intersubjetivamente compartilhada por modelos mentais responsáveis para organização do nosso conhecimento na mente, sendo esta última, o resultado da interação entre o corpo do sujeito e suas experiências. Como ocorre este processo?

A comunicação humana é mediada por textos. Desde o sempre da nossa existência enquanto sujeitos, compartilhamos objetos do discurso com os outros baseados em contextos de 
interação específicos, cujos sentidos são publicamente negociáveis, e não uma etiquetagem racional e solipsista. Segundo Castells (2015, p. 191),

a comunicação acontece quando as mentes são ativadas para compartilhar significado. A mente é um processo de criação e manipulação de imagens mentais (visuais ou não) no cérebro. As ideias podem ser consideradas arranjos de imagens mentais.

Portanto, a construção dos sentidos se realiza a partir da interação de mentes em contextos comunicativos socialmente estabelecidos e a partir de experiências discursivas organizadas em modelos mentais. Segundo Van Dijk (2012), modelos mentais são representações cognitivas de experiências discursivas vivenciadas pelo sujeito, englobando, além dos sentidos do texto, eventos associados a ele. Por esse motivo, a Linguística Cognitiva assume a ideia de que a mente é o resultado da experiência social (corpo, emoção e discurso (texto+contexto)) em que o sujeito é inserido desde o sempre da sua existência.

Assim, os objetos do mundo passam a ser objetos do discurso, pois são (re)construídos de forma situada em práticas socioculturais compartilhadas. A cognição humana é, portanto, social, tributária das experiências do sujeito e seu compartilhamento intersubjetivo do conhecimento em situações comunicativas vivenciadas.

No entanto, a condição heterogênea da produção do discurso e nas negociações públicas dos sentidos não legitima um "vale-tudo" hermenêutico e/ou semântico, quando se pode conferir qualquer sentido a qualquer objeto do discurso. Para Van Dijk (2012), os modelos mentais são pessoais e subjetivos, pois são a representação cognitiva da experiência do sujeito em sua mente. Porém, os modelos mentais sofrem restrições e condicionamentos estabelecidos pelas situações comunicativas que atuam de forma persuasiva e até mesmo coercitiva.

A atribuição dos sentidos revela-se, sob esta perspectiva, uma dimensão bem mais complexa que a relação sujeito e sentido dicionarizado.

\subsection{Texto, discurso, interpretação, modelos mentais e ideologia}

A comunicação humana tem, como visto, um complexo esquema de articulação que não se limita, como já dito, à etiquetagem de objetos do mundo. Toda comunicação se dá através de textos. Os textos são o produto/processo da interação, meio através do qual o conhecimento se manifesta e se materializa. O texto passa a ser o caminho cognitivo através do qual o sujeito manifesta sua percepção da realidade, usando como ferramenta cognitiva a linguagem. A linguagem se torna um instrumento de tratamento da realidade, e não uma isomorfia desta, uma representação objetiva do mundo externo à mente do sujeito.

Porém, os textos não são produzidos aleatoriamente, menos ainda em condições repetíveis e padronizadas: são produzidos discursivamente. Aqui, o discurso funciona como condições de produção do texto e da interação, as quais englobam desde os papéis sociais dos partícipes da interação até o conhecimento a respeito dos objetos do discurso negociados na interação. A noção de discurso está atrelada à de modelos mentais, pois estes devem ser entendidos como representações cognitivas das experiências do sujeito (cf. VAN DIJK, 2012). Regras comportamentais, seleção lexical e de conteúdo, níveis de registro de linguagem, dentre outros elementos, compõem as regras do discurso, que serão armazenadas dentro de um modelo mental. Exemplificando, ministros do STF possuem modelos mentais sobre aborto, financiamento privado de campanhas e liberdade de imprensa a depender da situação comunicativa em que se encontram (uma audiência, uma entrevista, uma sessão com os demais ministros), de sorte que seus textos sofrerão pressões discursivas a respeito do que é possível dizer.

A interpretação, dentro deste esquema, apresenta-se como um processo de construção e atribuição de sentidos. Essa perspectiva difere de uma noção de interpretação que traduz um

Revista de Direito Brasileira | São Paulo, SP | v. 19 | n. 8 | p. 315 - 334 |Jan./Abr. 2018 
sentido estático e prévio, cuja função do intérprete é apenas reiterá-lo em seus discursos. Antes, a interpretação é resultado da negociação pública do conhecimento em situações comunicativas socialmente estabelecidas, sendo possível, sim, que os sentidos sejam fluidos e tributários dos contextos em que são construídos.

Como já dito, a noção fundamental nesta abordagem é a de modelo mental. E é justamente na articulação entre modelo mental, conhecimento e interpretação, que podemos falar em ideologia. Um modelo de análise comportamental do STF com base em critérios ideológicos foi proposto por Mello (2016). No entanto, a abordagem das mutações constitucionais compreende a ideologia como um sistema de crenças que se alinham discursivamente com outros discursos, que, por sua vez, fundamentam modelos mentais exteriorizados pelos sujeitos - neste caso, os ministros do STF.

Portanto, quando um ministro do STF defende uma interpretação, uma atribuição de sentido(s) a uma norma constitucional, ele o faz exteriorizando, através do texto, sua percepção a respeito do objeto do discurso, percepção esta que está ligada às condições discursivas do ato de perceber - ou seja: a noção que ele tem, por exemplo, sobre o aborto, não é derivada da sua razão, mas de como ele percebeu e construiu, dentro de um determinado contexto sociodiscursivo, tal conceito, o que engloba suas experiências sociais (inclusive corpóreas, se estivermos falando de ministros e ministras; formação religiosa, as posições políticas, etc.).

Assim sendo, a interpretação possui um lastro que condiciona o(s) sentido(s) atribuídos pelo sujeito na interação, e que estão intrinsicamente ligados aos modelos mentais que ele construiu a partir de suas experiências.

Mas, em matéria de interpretação jurídica, como lidar com a heterogeneidade dessas interpretações. O fato de elas serem possíveis seria condição para legitimá-las? O poder de dizer/atribuir o sentido é suficiente para dar a "última palavra" sobre o que é tal conceito jurídico?

Discutir um fato social dentro ou fora das práticas judiciárias faz toda a diferença na ativação de determinados modelos mentais, pois mudam as condições de produção do discurso, o que se reflete na materialidade do texto, sobretudo nas seleções lexicais, sendo que o léxico é uma das principais formas de ativação de modelos mentais, além de todo um ritual processual e de uma ordem cognitiva em termos de conteúdo previamente estabelecidos pela própria ordem constitucional. Dessa forma, a ruptura constitucional de uma mutação não pode prescindir das regras estabelecidas na e pela ordem constitucional que estabelece os parâmetros interpretativos, ainda que os intérpretes tenham modelos mentais, cujo conteúdo seja paradoxal ao que uma constituição estabeleça.

É possível que aí resida a questão da manutenção da ordem constitucional democrática e o respeito às regras estabelecidas por essa ordem e os limites e possibilidades de os sujeitos autorizados para tanto romper e/ou modificar essa ordem.

Não há lugar melhor para discutir e analisar essa tênue relação que o próprio texto.

\subsection{Voltando à mutação inconstitucional da garantia da presunção da inocência: uma abordagem sociocognitiva do discurso}

A análise aqui proposta guarda certo grau de ineditismo. Apesar da profundidade com que teóricos já se debruçaram sobre as relações em Direito e Linguagem, análises que levem em consideração a perspectiva acima mencionada não são encontradas na mesma proporção.

Já fizemos, aqui, uma análise jurídica da questão. Mas, a partir de agora, direcionamos as atenções aos textos normativos, buscando reconstruir o seu desenvolvimento pelo sujeito, a partir da vinculação de suas opções lexicais e argumentativas com vistas à aceitabilidade do seu texto por parte do auditório. A linguagem é, como já disse Steven Pinker, uma janela para a mente, e o texto, um caminho para o acesso à cognição, às formas de percepção do sujeito frente 
ao mundo que se lhe apresenta. Sua forma de agir a esse contexto (histórico, social, cultural e toda a sua complexidade) representa respostas linguísticas a demandas que lhe são impostas discursivamente. Não que o sujeito seja simplesmente condicionado. Antes, é um processo de escolha e estratégia linguístico-argumentativa a fim de solucionar questões de persuasão e aceitação do texto que produz.

Como afirma Koch (2002, p. 193):

Os textos, como formas de cognição social, permitem ao homem organizar cognitivamente o mundo. E é em razão dessa capacidade que também são excelentes meios de intercomunicação, bem como de produção, preservação e transmissão do saber. Determinados aspectos de nossa realidade social só são criados por meio da representação dessa realidade e só assim adquirem validade e relevância social, de tal modo que os textos não apenas tornam o conhecimento visível, mas, na realidade, sociocognitivamente existente. A revolução e evolução do conhecimento necessita e exige, permanentemente, formas de representação notoriamente novas e eficientes. (negritos nossos)

Portanto, os textos são representações linguísticas de representações mentais do produtor do texto. Sua produção pressupõe escolhas lexicais, sintáticas e discursivas que refletem a forma pela qual o mundo é percebido por aquele que os produz.

Assim, voltamo-nos à análise do voto do Min. Luís Roberto Barroso para analisarmos as questões pontuais dos aspectos sociocognitivos dos textos no que tange à construção de frames (modelos mentais). Outros votos e outras categorias de análise de que tratam a Teoria Sociognitiva do Discurso (reframing, nominalizações, retomadas anafóricas, etc.) poderiam ser abordados, mas, por questões de espaço, limitar-nos-emos à noção de modelo mental/frame.

\subsubsection{Construindo modelos mentais ou frames}

Como dissemos anteriormente, os modelos mentais são intersubjetivos, pois lidam com a matéria-prima da realidade social e são internalizados pelo sujeito que enquadra (frame) determinados objetos do discurso segundo sua percepção e experiência de mundo.

Assim, quando, no caso analisado, um juiz constrói uma mutação constitucional, ou seja, uma mudança de interpretação do que seria uma suposta literalidade do texto constitucional, ele precisa, antes de tudo, criar um enquadramento (framing) da sua visão, buscando alinhar sua perspectiva com o mundo exterior, com a realidade social a qual pretende aderir (ideologia = sistema de crenças alinhadas). Essa construção textual se realiza pela atividade de gerar tópicos discursivos, que são, nada mais nada menos, como que um tema que vai centralizar a linha argumentativa do seu texto a fim de conferir-lhe coerência. Mas, antes de tudo, esse tópico deve ativar na mente dos leitores/ouvintes, frames e modelos mentais para que sua argumentação e conclusão, ao fim da produção, sejam aceitas por eles.

Vejamos este trecho da ementa (com negritos nossos), logo no início do voto do Min. Roberto Barroso:

1. A interpretação que interdita a prisão quando já há condenação em segundo grau confere proteção deficiente a bens jurídicos tutelados pelo direito penal muito caros à ordem constitucional de 1988, como a vida, a segurança e a integridade física e moral das pessoas (CF/1988, arts. 5º caput e LXXVIII e 144). $O$ enorme distanciamento no tempo entre fato, condenação e efetivo cumprimento da pena (que em muitos casos conduz à prescrição) impede que o direito penal seja sério, eficaz e capaz de prevenir os crimes e dar satisfação à sociedade. Desse modo, muito embora uma das leituras possíveis do art. 283 do Código de Processo Penal (com redação dada pela Lei $n^{\circ}$ 
12.403/2011) limite a prisão às hipóteses de trânsito em julgado, prisão temporária ou prisão preventiva, deve-se conferir ao preceito interpretação que o torne compatível com a exigência constitucional de efetividade e credibilidade do sistema de justiça criminal.

Podemos identificar, de pronto, a construção do tópico discursivo do Ministro, delimitando, desde já, um frame, um enquadramento de qual perspectiva será tratada a questão. Dizer que alguns institutos legais impedem que "o direito penal seja levado a sério" e que é necessário "dar satisfação à sociedade", além de promover interpretações que promovam a "efetividade e credibilidade do sistema de justiça criminal" já revela um alinhamento do discurso do Ministro com os apelos populares e a indignação, por parte deste mesmo povo, com uma justiça lenta e que não pune com o devido rigor, ao menos na sua visão, os crimes cometidos. Ao falar em impunidade, falta de efetividade e de credibilidade do sistema criminal, o Ministro invoca em seu auditório os modelos mentais sobre o que comumente se pensa sobre tal seara do Direito. Vale salientar que os modelos mentais de uma justiça criminal inoperante e benéfica a criminosos é diariamente alimentada por telejornais das mais diferentes categorias.

Assim, o Ministro busca uma espécie de álibi discursivo-jurídico para sedimentar a mutação constitucional, ao mesmo tempo em que constrói, no texto, um modelo mental que se alinha com a vontade popular ou da sociedade, a fim de lhe assegurar aprovação social, haja vista que, especificamente, o tema em debate e a mídia que levará a informação da decisão do STF irão repercutir sobre quem decidiu e o que se decidiu acerca da questão constitucional.

A mesma estratégia é usada no decorrer da sua argumentação, antes de citar exemplos clássicos da jurisprudência que sustentam a tese do seu voto. Embora seja óbvio para qualquer operador jurídico ou mesmo para uma criança em uma loja de brinquedos que quer convencer o pai a comprar um caro Lego, na estratégia discursiva são escolhidos para sedimentar uma tese apenas os casos e exemplos que vão ao seu encontro. Assim, o Ministro referido controla totalmente o tópico discursivo e ativa na mente de seu auditório sinapses que se organizarão no modelo mental acionado e se fortalecerão na memória desse auditório. Vejamos:

O sistema penal brasileiro não tem funcionado adequadamente. A possibilidade de os réus aguardarem o trânsito em julgado dos recursos especial e extraordinário em liberdade para apenas então iniciar a execução da pena enfraquece demasiadamente a tutela dos bens jurídicos resguardados pelo direito penal e a própria confiança da sociedade na Justiça criminal. Ao se permitir que a punição penal seja retardada por anos e mesmo décadas, cria-se um sentimento social de ineficácia da lei penal e permite-se que a morosidade processual possa conduzir à prescrição dos delitos. Alguns exemplos emblemáticos auxiliam na compreensão do ponto. (negritos nossos)

Reitera-se, nesse ponto do texto, os mesmos tópicos discursivos criados. A repetição dos tópicos discursivos é fundamental para manter a atenção do auditório e a ativação constante dos modelos mentais ativados. Os trechos em negrito demonstram a habilidade argumentativa do Ministro em manter o tópico dentro de um mesmo modelo mental a fim de garantir-lhe a coerência interna (cotextual) e o seu alinhamento ideológico com a aceitação do auditório pelas teses (contextual).

Quando cita os exemplos, o Ministro cria, ao fim de cada um deles, uma espécie de epílogo, retomando expressões que estão fortemente associadas ao frame e ao tópico discursivo por ele criado no início do texto. É sempre importante salientar que os modelos mentais são compartilhados. Dentro dos modelos mentais existem frames diferentes (ex: eu posso concordar com a impunidade e ineficiência da justiça criminal sem, no entanto, concordar com linchamentos ou qualquer outra forma que não a estabelecida em lei para punir todos os crimes). 
Assim, quando um produtor textual quer ativar um modelo mental e quer que o auditório "enquadre" os objetos e as palavras associada a esse modelo mental, deverá citar palavras e/ou expressões que reforce o enquadramento pretendido, criando na mente dos membros do auditório a situação de pertencimento (experiências, emoções) e, ao fim, estabelecendo o alinhamento ideológico (passam a crer na mesma coisa e da mesma forma).

Vejamos os "epílogos" criados pelo Ministro ao fim de cada exemplo citado. Recomendamos a leitura na íntegra do texto a fim de melhor contextualizar o porquê de cada epílogo. Por limites de espaço, não poderíamos aqui citar a íntegra desse trecho.

"O sistema que tínhamos não era garantista. Ele era grosseiramente injusto e estimulava as pessoas a voltarem ao tempo da vingança privada e quererem fazer justiça com as próprias mãos.

O sistema que tínhamos não era garantista. Ele era grosseiramente injusto e difundia a impressão de que neste país o crime compensa.

O sistema que tínhamos não era garantista. Ele era um golaço da impunidade.

O sistema que tínhamos não era garantista. Ele era grosseiramente injusto e funcionava como estímulo aos comportamentos mais bárbaros, ao primitivismo puro e simples.

Isso não é garantismo. É a desmoralização do país perante a comunidade internacional, que acompanha o caso com interesse.

Quando se colocam nomes, sentimentos, sofrimentos, inconformismo, o absurdo do sistema fica mais visível." (negritos do autor)

O estilo aqui utilizado torna ainda mais evidente a estratégia de vincular a interpretação dada ao texto constitucional e ao penal a mutação defendida pelo Ministro. A seleção lexical e a criação de uma estrutura frasal semelhante ("O sistema que tínhamos...”) faz com que o ouvinte/leitor se mantenha preso ao tópico discursivo, ao passo que os modelos mentais serão ativados e alinhados numa mesma perspectiva. A estratégia discursiva intenta, também, justificar àqueles que não concordam com a interpretação do Ministro, e por isso ele recorre aos itens lexicais "justiça com as próprias mãos", "o crime compensa", "impunidade", "estímulo aos comportamentos bárbaros", "desmoralização do país", "inconformismo", a fím de tentar, também, provocar o "reframing": não apenas mudar a opinião, mas também reorganizar, na mente daqueles que não concordam com sua argumentação, a estrutura de seus modelos mentais (por isso, às vezes, é tão difícil mudar de opinião, pois isso requer um esforço cognitivo que nem sempre o cérebro está disposto a fazer).

Muitos outros aspectos poderiam ser abordados aqui. Mas este tipo de perspectiva analítica nos parece ser muito útil em tempos de espetacularização da justiça, sobretudo do STF. Se a interpretação é subjetiva, deve existir um mecanismo de controle da interpretação para que haja, de fato, um limite interpretativo, sobretudo quando se trata da interpretação constitucional. Justamente por haver elementos subjetivos e ideológicos, os limites interpretativos devem estar claros e barrar textos que extrapolem limites textualmente explícitos na própria constituição. Não significa advogar a existência de uma Corte Constitucional insensível a demandas sociais e aos sentimentos que permeiam suas relações. Contudo, achamos apropriada uma metáfora em que o juiz constitucional está em uma caixa de vidro transparente ao decidir: ele vê o seu entorno, consegue enxergar, sentir o que o seu ao redor social sente. Mas os limites constitucionais são as paredes de vidro. Se o juiz constitucional quiser ir ao encontro do povo, passando dos limites, ele choca-se ao vidro. 


\section{CONCLUSÃO}

Apesar de não existir um consenso sobre a melhor filosofia e método de interpretação do direito, o debate hermenêutico contemporâneo busca escapar tanto do formalismo exegético oitocentista, quanto do positivismo semântico, que flerta com o realismo jurídico ao conferir ampla discricionariedade ao intérprete judicial. Ainda que teorias interpretativas atuais, construídas sob o paradigma do constitucionalismo democrático do pós-Segunda Guerra, tenham desenvolvido novas categorias para conferir concretude aos valores substantivos e direitos fundamentais constitucionalizados, sua utilização na práxis nacional tem conduzido a uma elevação do poder do juiz constitucional. A distorção de referenciais teóricos e correntes doutrinárias tem servido para camuflar práticas judiciais decisionistas, influenciadas por fatores políticos e/ou ideológicos não filtrados pela ordem constitucional. Como consequência, constatase a existência de mutações inconstitucionais, que, antes de promoverem avanços no conteúdo da constituição, representam uma expansão excessiva dos poderes decisórios do STF, em detrimento do âmbito de atuação do legislador democrático, caracterizando um movimento ativista do Tribunal.

\section{REFERÊNCIAS BIBLIOGRÁFICAS}

ADEODATO, João Maurício Leitão. Jurisdição constitucional à brasileira: situação e limites. In: Congresso Nacional de Estudos Tributários. São Paulo: Noesis, 2006. p. 323-342.

CAPPELLETTI, Mauro. O controle judicial de constitucionalidade das leis no direito comparado. 2. ed. Porte Alegre: Sergio Antonio Fabris, 1999.

CASTELLS, Manuel. O poder da comunicação. São Paulo: Paz e Terra, 2015.

DIMOULIS, Dimitri. Positivismo jurídico: introdução a uma teoria do direito e defesa do pragmatismo jurídico-político. São Paulo: Método, 2006. (Coleção Professor Gilmar Mendes, 2).

FALCONE, Karina. A legitimação e o processo de categorização social. In: Revista Veredas. Número atemático. Volume 1. PPG Linguística - UFJF, 2011. pp. 16-31.

FERRAZ, Anna Cândida da Cunha. Processos informais de mudança da Constituição: mutações constitucionais e mutações inconstitucionais. São Paulo: Max Limonad, 1986. (Série Jurídica Max Limonad, n. 1).

FERRAZ JR., Tércio Sampaio. Introdução ao estudo do direito: técnica, decisão, dominação. 2. ed. São Paulo: Atlas, 1994.

- O Judiciário frente à divisão de poderes: um princípio em decadência? In: Anuário dos Cursos de Pós-Graduação em Direito, Recife: Universidade Federal de Pernambuco, n. 11, 2000, pp. 345-359.

FISHER, Louis. Constitutional dialogues: interpretation as political process. Princeton University Press, 1988.

HART, Herbert Lionel Adolphus. O conceito de direito. Tradução de A. Ribeiro Mendes. 4. ed. Lisboa: Fundação Calouste Gulbenkian, 2005. 
. Essays in Jurisprudence and Law. Clarendon Press: Oxford, 1983.

KELSEN, Hans. Jurisdição constitucional. São Paulo: Martins Fontes, 2003.

1985.

. Teoria pura do direito. Tradução de João Baptista Machado. São Paulo: Martins Fontes,

LEITE, Glauco Salomão; TEIXEIRA, João Paulo Allain. El pensamiento jurídico brasileño y la reconstrucción de la Dogmatica Constitucional pos-1988: el neoconstitucionalismo y la trampa del protagonismo judicial. In: LEITE, Glauco Salomão; LEITE George Salomão;

STRAUSS, David A. The living constitution. Oxford: Oxford University Press, 2010.

STRECK, Lenio (orgs). Neoconstitucionalismo: avances y retrocesos. Valencia: Tirant lo Blanch, 2016, pp. 67-90.

JUST, Gustavo. Interpretando as Teorias da Interpretação. São Paulo: Saraiva, 2014.

KOCH, Ingedore Grunfeld Villaça. 2012. Desvendando os segredos do texto. $4^{\mathrm{a}}$ ed. São Paulo: Cortez, 2002.

MARCUSCHI, Luiz Antonio. A Construção do Mobiliário do Mundo e da Mente: linguagem, cultura e categorização, In: MIRANDA, N. S. \& NAME, M. C. (orgs.) Linguística e Cognição. Juiz de Fora, Editora UFJF, 2005. pp. 49-78.

MELLO, Patricia Perrone Campos. Nos bastidores do STF. Rio de Janeiro: Forense, 2015.

MONTESQUIEU, Charles de Secondat, Baron de. O espírito das leis. Tradução de Cristina Murachco. 2. ed. São Paulo: Martins Fontes, 1996.

OTTO, Ignacio de. Derecho constitucional: sistema de fuentes. 4. reimpr. Madrid: Ariel, 1995.

PERELMAN, Chäim. Lógica jurídica. Tradução de Vergínia K. Pupi. São Paulo: Martins Fontes, 2004.

PIRES, Bruno. Gilmar Mendes e Luiz Fux batem boca em sessão do TSE. In: Folha de São Paulo, Caderno Política, 15 de dezembro de 2016.

REIS, Isaac. Entre o pesadelo e o nobre sonho: a hermenêutica da incerteza e a retórica da objetividade. In: JUST, Gustavo; REIS, Isaac (orgs.). Teoria Hermenêutica do Direito: autores, tendências e problemas. Recife: Editoria Universitária UFPE, 2012, pp. 147-176.

RODRIGUES-LEITE, Jan Edson. A Natureza Social da Cognição: questões sobre a construção do conhecimento. Veredas: revista de estudos linguísticos. Vol. 7, no 1 e $\mathrm{n}^{\mathbf{o}}$ 2. Jan/Dez 2003. pp. 217-232.

SANTOS, Boaventura de Sousa. Um discurso sobre as ciências. São Paulo. Cortez, 1987. 
STRECK, Lenio Luiz. Verdade e Consenso: Constituição, Hermenêutica e Teorias Discursivas. Da possibilidade à necessidade de respostas corretas no Direito. $2^{\mathrm{a}}$ ed. Rio de Janeiro: Lumen Juris, 2008.

STRUCHINER, Noel. Direito e Linguagem: uma análise da textura aberta da linguagem e sua aplicação ao Direito. Rio de Janeiro: Renovar, 2002.

VAN DIJK, T.A. Discurso, Notícia e Ideologia: estudos na Análise Crítica do Discurso. Porto, Campo das Letras, 2005.

VAN DIJK, T. A. Discurso e Produção do Conhecimento, In: BRAIT, B. \& SOUZA-E-SILVA, M. C. Texto ou Discurso? São Paulo, Contexto, 2012. pp. 257-268. 